\title{
1 DNA-damage induced cell death in yap1;wwtr1 mutant epidermal basal cells
}

2 Jason K. H. Lai ${ }^{1, *}$, Pearlyn J. Y. Toh ${ }^{1}$, Hamizah A. Cognart ${ }^{1}$, Geetika Chouhan ${ }^{2}$ \& Timothy 3 E. Saunders ${ }^{1,3,4,5, *}$

$4 \quad{ }^{1}$ Mechanobiology Institute, National University of Singapore, Singapore 117411

$5{ }^{2}$ Department of Biological Sciences, Tata Institute of Fundamental Research, Colaba,

6 Mumbai, India

$7 \quad{ }^{3}$ Department of Biological Sciences, National University of Singapore, Singapore 117558

$8{ }^{4}$ Institute of Molecular and Cell Biology, A*Star, Singapore

$9 \quad{ }^{5}$ Warwick Medical School, University of Warwick, United Kingdom

10 * Corresponding authors: J. K. H. L. (jason.lai@nus.edu.sg), T. E. S.

11 (timothy.saunders@warwick.ac.uk) 


\section{ABSTRACT}

14 In a previous study, it was reported that Yap1 and Wwtr1 in zebrafish regulates the 15 morphogenesis of the posterior body and epidermal fin fold (Kimelman, D., et al. 2017). We 16 report here that DNA damage induces apoptosis of epidermal basal cells (EBCs) in zebrafish 17 yap1 $1^{-/} ; w_{w t r} 1^{-/}$embryos. Specifically, these mutant EBCs exhibit active Caspase-3, Caspase188 and $\gamma \mathrm{H} 2 \mathrm{AX}$, consistent with DNA damage serving as a stimulus of the extrinsic apoptotic 19 pathway in epidermal cells. Live imaging of zebrafish epidermal cells reveals a steady 20 growth of basal cell size in the developing embryo, but this growth is inhibited in mutant 21 basal cells followed by apoptosis, leading to the hypothesis that factors underscoring cell size play a role in this DNA damage-induced apoptosis phenotype. We tested two of these factors using cell stretching and substrate stiffness assays, and found that HaCaT cells cultured on

24 stiff substrates exhibit more numerous $\gamma \mathrm{H} 2 \mathrm{AX}$ foci compared to ones cultured on soft substrates. Thus, we propose that substrate rigidity modulates genomic stress in the developing epidermal cell, and that Yap1 and Wwtr1 are required for its survival. 


\section{INTRODUCTION}

The Hippo signalling pathway is widely known for its role in regulating tissue and organ size (Johnson \& Halder, 2014). More recently, the roles of its downstream effectors, Yap1 and Wwtr1 (or widely referred to as Taz), have been described in a variety of developing tissues. In the developing heart, Wwtr1 participates in cardiomyocyte decision-making to become a trabecular cell (Lai et al., 2018). Additionally, in the cardiovascular system, YAP1 and WWTR1 are important for sprouting angiogenesis (Astone et al., 2018; Kim et al., 2017; Neto et al., 2018; Wang et al., 2017) and vascular stability (Nakajima et al., 2017). Yap1 and Wwtr1 also regulate the retinal epithelium cell fate in the eye (Miesfeld et al., 2015), kidney branching morphogenesis (Reginensi et al., 2015) and fibronectin assembly for tail morphogenesis (Kimelman et al., 2017). In this report, we show that Yap1 and Wwtr1 are required for the survival and growth of epidermal cells during skin development.

In the zebrafish, the non-neural ectoderm, marked by $\triangle N p 63$, emerges from the ventral side of the gastrulating embryo, and spreads dorsally to cover the entire embryo as a sheet of cells beneath the periderm during segmentation stages (Bakkers et al., 2002; Solnica-Krezel, 2005). Residing in this layer are the epidermal basal cells (EBCs) which are responsible for epidermal cell renewal and homeostasis (Blanpain \& Fuchs, 2006). In mice, Yap1 and Wwtr1, acting downstream of integrin signalling, were shown to modulate EBC proliferation during wound healing (Elbediwy et al., 2016). However, their role in early epidermal development is poorly characterised.

In addition to their role in cell proliferation, YAP1 and WWTR1 promote cell survival. When cells are challenged with DNA damaging agents including doxorubicin (Ma et al., 2016) and radiation (Guillermin et al., 2021), YAP1, as a co-transcription factor of Teads, is localised in the nucleus to drive expression of pro-survival genes. Indeed, transgenic expression of Yapl in murine livers upregulates the expression of Survivin (Birc5) in hepatocytes, protecting these cells from apoptosis when treated with a pro-apoptotic agent, Jo-2 (Dong et al., 2007). On the other hand, genetic knock-down of Yapl or inhibition of YAP1 nuclear localisation exaggerates apoptosis in cells exposed to chemo- and radiotherapy (Guillermin et al., 2021; Ma et al., 2016). Thus, YAP1 executes its pro-survival function in the nucleus by driving the expression of target genes.

In this study, we show that concurrent loss of yapl and wwtrl results in aberrant apoptosis of EBCs on the yolk at the 6-10 ss. However, epidermal cell proliferation is not reduced in yap 1; wwtrl double mutant zebrafish embryos, in contrast to adult $\mathrm{Yapl}^{-/-}$;Wwtr1 ${ }^{-/-}$mice. At these developmental stages, Yap1 and Wwtrl are localised in the EBC nuclei to putatively carry out their co-transcriptional function through the Tead-Binding Domain and support epidermal cell survival. This cell death phenotype in mutant embryos is executed through the extrinsic apoptotic pathway, as apoptosis assays reveal activation of Caspase- 8 and Caspase3. Further, we show that $\gamma \mathrm{H} 2 \mathrm{AX}$, a DNA damage marker, is recruited in mutant EBCs. Thus, DNA damage prompted the extrinsic apoptotic pathway in these cells (Hill et al., 1999). Live imaging of epidermal cells found that, leading up to this apoptosis phenotype, mutant basal cell growth is inhibited after the 6 ss, unlike their sibling embryo counterparts, which continue to grow. Interestingly, human keratinocytes cultured on stiffer substrates exhibit more $\gamma \mathrm{H} 2 \mathrm{AX}$ foci than cells cultured on softer substrates, suggesting that the mechanical environment not only modifies cell size, but also plays a role in genomic stress. 
bioRxiv preprint doi: https://doi.org/10.1101/2021.07.23.453490; this version posted July 23, 2021. The copyright holder for this preprint

(which was not certified by peer review) is the author/funder, who has granted bioRxiv a license to display the preprint in perpetuity. It is made available under aCC-BY 4.0 International license.

74 Thus, we propose that in response to genomic stress, Yap1 and Wwtr1 have important roles

75 in the survival of EBCs during the course of their development. 


\section{RESULTS}

\section{Yap1 and Wwtr1 are localised in the nuclei of epidermal basal cells to modulate their survival}

The previous work on yap 1;wwtrl double mutant zebrafish reported no overt cell death in the tail (Kimelman et al., 2017). We focused on the lateral yolk, on which two layers of the epidermis - the periderm and basal epidermis - reside. We performed TUNEL assays on 16-

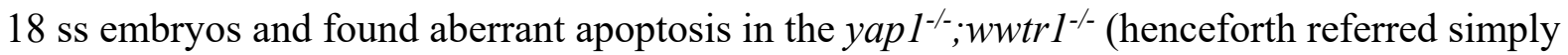
as 'mutant') epidermis on the yolk, but not in the tail as reported before (Figure 1A). Additionally, whereas WT embryos have regular distribution of P63-positive nuclei (an EBC marker) over the yolk, mutants have a more irregular and sparser pattern (Figure 1A), suggesting apoptosis of mutant EBCs. We investigated this phenotype in closer detail by repeating this assay in younger embryos and imaging them with higher magnifications. Normal sibling epidermis exhibit virtually no TUNEL signal. On the other hand, mutant epidermis exhibit P63 and TUNEL co-staining (apoptotic EBCs), as well as punctate TUNEL signal. The latter corresponds to apoptotic fragments that made up the bulk of the TUNEL signal (Figure 1B and B'). Therefore, Yap1 and Wwtr1 are required for EBC survival.

Using previously characterised antibodies against Yap1 and Wwtr1 (Flinn et al., 2020; Kimelman et al., 2017; Lai et al., 2018; Miesfeld et al., 2015), we investigated their cellular localisation in the epidermis. Both Yap1 and Wwtr1 are localised in the nuclei of the peridermis and basal epidermis at the tailbud stage and at the 16-20 ss (Figure 2). Yap1 is also localised to the junctions of peridermal cells (Figure 2; Flinn et al., 2020). At these developmental stages, some EBCs in the basal epidermis lose P63 expression and differentiate into ionocytes (Jänicke et al., 2007). By comparing P63-positive to P63negative nuclei in the basal epidermis, we found greater expression levels of Yap1 and Wwtr1 in the P63-positive ones (Figure 2-figure supplement 1A), indicating Yap1 and Wwtr1 activity in EBCs.

In the nucleus, Yap1 and Wwtr1 bind to Teads via their Tead-Binding Domain (TBD) to drive expression of target genes. To test whether this interaction is important for their function, we evaluated the yap $1^{\text {bns22 }}$ zebrafish allele which encodes an in-frame deletion in the TBD of Yap1 (p.(Pro42_Glu60delinsLeu)) (Figure 2-figure supplement 1B). Specifically, this deletion spans across the S54 residue that binds to Teads (Miesfeld et al., 2015; Zhao et al., 2008). In the yap $1^{\text {bns22/bns22 }}$;wwtr $1^{-/}$embryos, we again observed apoptosis in the epidermis (Figure 2-figure supplement 1B'). These observations suggest that nuclearlocalised Yap1 in EBCs promote survival by driving the expression of downstream target genes with Teads.

\section{Yapl and Wwtrl are dispensable for the proliferation of developing epidermal cells}

Using adult mice, a previous study found fewer proliferating cells in the epidermis of Yap 1;Wwtr 1 double mutants (Elbediwy et al., 2016). Thus, we performed a proliferation assay with phospho-histone $\mathrm{H} 3 \mathrm{(pH3)}$ staining in the 3-5 ss embryos. We chose this developmental stage to avoid coinciding with the cell death phenotype in mutants. Overall, the number of $\mathrm{pH} 3$ foci is not noticeably different between WT and mutant embryos (Figure 3 ). Restricting our analysis to the epidermis on the lateral yolk, the number of $\mathrm{pH} 3$ positive 
cells is not significantly different between the two genotypes (Figure 3B). Thus, Yap1 and Wwtr1 are not required for epidermal cell proliferation during development.

\section{Apoptosis in mutant EBCs occurs through the extrinsic pathway}

We next address whether the apoptosis phenotype in mutant EBCs is initiated by the intrinsic or extrinsic pathway. Supporting the TUNEL results, we find in mutant epidermis, cleaved Caspase-3 co-stained with P63 and in apoptotic fragments (Figure 4A and A'). To test the extrinsic pathway, we evaluated the activity of Caspase- 8 using a live Caspase- 8 probe, FITC-IETD-FMK. At the 18-20 ss, FITC foci are present in mutant, but not WT, epidermal cells (Figure 4B and B'), indicating that Caspase- 8 is active in mutants. In addition, the apoptosis phenotype is indistinguishable between mutant embryos with and without morpholino knock-down of tp53 (Figure 4-figure supplement 1A). Taken together, apoptosis in yap 1;wwtr 1 double mutant epidermal cells is initiated by the extrinsic pathway and is independent of Tp53.

\section{$\gamma H 2 A X$ is recruited to the nuclei of mutant epidermal cells}

Previous studies have found that the epidermis clears DNA-damaged cells through the extrinsic apoptotic pathway (Bang et al., 2003; Hill et al., 1999; Takahashi, 2001), prompting us to investigate our mutant epidermal cells for DNA damage. Indeed, interrogating mutant and WT embryos by Western Blot shows elevated levels of $\gamma \mathrm{H} 2 \mathrm{AX}$, a DNA damage marker, in mutants (Figure 4-figure supplement 1B). Closer inspection of these embryos by confocal microscopy reveals a pan-nuclear pattern of $\gamma \mathrm{H} 2 \mathrm{AX}$ in mutant EBCs but not in WT ones (Figure 4C and $\mathrm{C}^{\prime}$ ). $\gamma \mathrm{H} 2 \mathrm{AX}$ was also observed in apoptotic fragments. Therefore, DNA damage is the putative stimulus of the extrinsic apoptotic pathway in mutant EBCs.

\section{Mutant basal cell size growth is limited}

What are the cellular events leading to apoptosis in mutant embryos? We utilised live imaging of the developing epidermis in order to visualise the cell behaviour. Embryos at the one-cell stage were injected with H2A-mCherry and lyn-EGFP mRNA to mark the nuclei and membrane, respectively. At the tailbud stage, we mounted the embryos laterally on the yolk to record the epidermal cells. In sibling and yap 1;wwtrl double mutants, epidermal cell behaviour is not readily distinguishable between them throughout the live imaging experiment, aside from apoptosis in mutant embryos beginning from the 3-hour mark (Movie S1).

With the membrane marker, we measured basal cell size in sibling and mutant embryos. Whereas basal cells in sibling embryos grew steadily throughout the live-imaging experiment, mutant ones stopped growing 120 minutes post-tailbud (Figure 5). At the end of this experiment, basal cells in sibling embryos were on average a third larger than mutant ones $\left(747 \pm 136 \mu \mathrm{m}^{2}\right.$ vs. $551 \pm 103 \mu \mathrm{m}^{2}$ [mean \pm s.d.]; $\left.P<0.01\right)$. Curiously, apoptosis DNA condensation and membrane blebbing (Movie S2) - of mutant basal cells follows after stagnation of their growth (Figure 5). We investigated cell shape parameters as well, but we did not observe any clear differences between mutant and sibling embryo basal cells. Taken together, basal cell growth is inhibited in yap 1;wwtr 1 double mutant embryos.

\section{Investigation of $\gamma H 2 A X$ by cell stretching and substrate stiffness}


159 Our results show that DNA damage is an upstream trigger of extrinsic apoptosis in mutant

160 EBCs, and that apoptosis occurs after inhibition of cell size. Thus, we hypothesised that

161 factors underlying cell size play a role in DNA damage. We tested this hypothesis with two

162 experiments: (1) in vivo stretching of head epidermal cells by ventricular inflation; and (2)

163 culturing of a human keratinocyte cell line, HaCaT, on increasing stiffness of collagen-coated

164 hydrogels.

165 We stretched epidermal cells in vivo by inflating the zebrafish brain ventricle with mineral oil

166 (Figure 6A) (Lewis et al., 2020). As a positive control, we exposed zebrafish embryos to UV

167 for 10 minutes followed by recovery of 1 hour before fixation. In the UV-treated embryos,

168 we found pan-nuclear staining of $\gamma \mathrm{H} 2 \mathrm{AX}$ in the periderm and basal epidermis (Figure 6-

169 figure supplement 1A), similar to the staining pattern in mutant EBCs (Figure 4C). However,

170 we did not observe $\gamma \mathrm{H} 2 \mathrm{AX}$ in the nuclei of epidermal cells after ventricular inflation (Figure

$\left.1716 \mathrm{~A}^{\prime}\right)$. These observations suggest that stretching of epidermal cells alone does not induce the

172 recruitment of $\gamma \mathrm{H} 2 \mathrm{AX}$.

173 Next, we evaluated DNA damage in HaCaT cells cultured on increasing substrate stiffness -

$1740.5 \mathrm{kPa}, 12 \mathrm{kPa}, 25 \mathrm{kPa}$ hydrogels and glass. One set of cells was exposed to UV as positive

175 controls. Interestingly, the number of $\gamma \mathrm{H} 2 \mathrm{AX}$ foci detected in $\mathrm{HaCaT}$ cell nuclei is higher in

176 cells cultured on stiffer substrates, but this correlation is not linear, with the maximum

177 number of foci occurring in $\mathrm{HaCaT}$ cells cultured on $12 \mathrm{kPa}$ hydrogel (Figure 6B).

178 Moreover, we observed a similar trend among cells exposed to UV (Figure 6-figure

179 supplement 1B). Nevertheless, in cells cultured on a given substrate stiffness, we detected

180 more $\gamma \mathrm{H} 2 \mathrm{AX}$ foci in the UV group than the unexposed group (Figure 6-figure supplement

181 1B). Thus, keratinocytes cultured on stiff substrates appear to have greater genomic stress

182 than cells on soft substrates. 


\section{DISCUSSION}

We report that Yap1 and Wwtr1 play important roles in epidermal cell size control and survival during epidermal development. In contrast to adult murine epidermis (Elbediwy et al., 2016), the developing zebrafish epidermis does not require Yap1 and Wwtr1 for cell proliferation. Instead, we found mutant epidermal cells to be smaller, exhibit DNA damage and undergo apoptosis through the extrinsic pathway. These observations led us to investigate the relationship between the mechanical environment of epidermal cells and genomic stress.

The mechanical environment of the developing epidermis changes with increasing production of the extracellular matrix (ECM). Indeed, greater ECM density is known to increase cell size (Engler et al., 2006), which could underscore the increasing basal cell size during epidermal development. In the transcriptomic signatures from the previous study (Kimelman et al., 2017), genes that are downregulated in yap 1; wwtrl double mutant tailbuds include lama5, col7a1, lamb1a, lamb4 and lamb2, which encode key components of the skin basal lamina. This downregulation likely translates to a different ECM environment in mutant embryos and consequently results in the inhibition of basal cell size (Figure 5).

Mechanical perturbations of cells were shown to recruit DNA damage factors including $\gamma \mathrm{H} 2 \mathrm{AX}$ and ATR (Cognart et al., 2020; Kumar et al., 2014). Our present results show that both baseline and induced DNA damage can be intensified by culturing cells on stiffer substrates. Specifically, we found more $\gamma \mathrm{H} 2 \mathrm{AX}$ foci in human keratinocyte cells seeded on $12 \mathrm{kPa}, 25 \mathrm{kPa}$ hydrogels and glass compared to the ones seeded on $0.5 \mathrm{kPa}$ hydrogels. Correspondingly, expression of genes encoding components of the skin basal lamina increases during the early segmentation stages (Baseline expression from transcriptional profiling of zebrafish developmental stages, Expression Atlas) (Papatheodorou et al., 2020). This increase may create an increasingly rigid environment (Engler et al., 2006) that perhaps results in greater baseline genomic stress in the developing EBCs, and thus require survival signals to counteract this stress. Previous investigations have already shown how Yap1 plays instrumental roles in providing this survival signal, including driving the expression of Survivin, under genomic stress (Guillermin et al., 2021; Ma et al., 2016). However, our Western Blot assay did not find downregulation of Survivin in zebrafish yap 1; wwtr 1 double mutants (data not shown), presumably as Survivin is also a key player in cellular proliferation (Nair et al., 2013), which is not impeded in mutants. Therefore, we propose that the mechanical environment of the epidermis modifies genomic stress in cells, and that Yap1 and Wwtr1 play a role in their survival.

Our work reveals that Yap1 and Wwtr1 have important functions in epidermal cell survival and growth during development. We also show greater genomic stress in cells grown on more rigid extracellular substrates, which likely explains the DNA damage-induced apoptosis phenotype in yap 1;wwtrl double mutant zebrafish. These results open new areas of exploration on the physiological relevance of mechanobiology in development, physiology and disease, as well as its interplay with Yap1/Wwtr1 and genomic stress in these processes. 


\section{MATERIALS \& METHODS}

\section{Ethics statement}

All zebrafish husbandry was performed under standard conditions in accordance with institutional (Biological Resource Center, A*Star, Singapore, and Tata Institute of Fundamental Research, India) and national ethical and animal welfare guidelines.

\section{Zebrafish lines}

Mutant zebrafish lines used in this study are: yap $1^{\text {bns19 }}$ (Astone et al., 2018; Kimelman et al.,

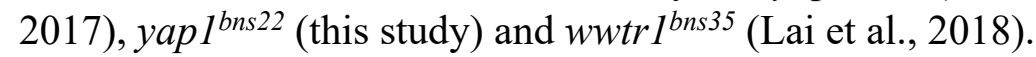

The yap $1^{\text {bns22 }}$ allele was generated from a CRISPR/CAS9-mediated mutagenesis. Two single-guide RNA (sgRNA) sequences, 5'-ACCTCATCGGCACGGAAGGG-3' and 5'CTGGAGTGGGACTTTGGCTC-3', were designed by a sgRNA design tool by the Zhang Lab (crispr.mit.edu; accessed in 2014). These sequences were cloned into the pT7-gRNA vector (Addgene \#46759). Following vector linearisation with BsmBI enzyme, sgRNA were obtained by in vitro transcription with MEGAshortscript T7 kit (Ambion). CAS9 mRNA was obtained by in vitro transcription of linearised pT3TS-nCas9n vector (Addgene \#46757) with MEGAscript T3 kit (Ambion). sgRNA (50 pg each) and $150 \mathrm{pg}$ of CAS9 mRNA were coinjected into one-cell stage $\mathrm{AB}$ embryos. The yap ${ }^{\text {bns22 }}$ allele contains a 54 bp deletion in the Tead-Binding Domain [p.(Pro42_Glu60delinsLeu)]. This allele can be genotyped by using the following PCR primer pair: 5'-CTGTTTGTGGTTTCTGAGGGG-3' and 5'CGCTGTGATGAACCCGAAAA-3'. Mutant and WT products can be resolved and distinguished by gel electrophoresis with a $2 \%$ gel. Genotyping of yap $1^{\text {bns } 19}$ and wwtr $1^{\text {bns } 35}$ alleles have been described previously (Astone et al., 2018; Lai et al., 2018).

Mutant embryos in this study were obtained from an incross of double heterozygous animals (i.e. yap $1^{\text {bns 19/+ }} ;$ wwtr $1^{\text {bns35/+ }}$ incross or yap $1^{\text {bns } 22 /+} ;$ wwtr $1^{\text {bns35/+ }}$ incross).

\section{Incubation and visual identification of mutant embryos}

Experiments involving 16 ss and older embryos were incubated at $25^{\circ} \mathrm{C}$ throughout, otherwise younger embryos were incubated at $28.5^{\circ} \mathrm{C}$.

yap1;wwtr1 double mutant embryos older than 16 ss can be visually identified for experiments. These mutant embryos were compared to stage-matched embryos from WT crosses.

For experiments involving $<16$ ss embryos, embryos from heterozygous incross were fixed and assayed for cell death with TUNEL. Using a wide-field stereomicroscope, embryos with excess TUNEL staining in the epidermis on the lateral yolk were selected and mounted for confocal imaging. Under the confocal microscope, embryos with apoptotic bodies (TUNEL foci and fragmented DNA stained by DAPI) were further investigated and genotyped for downstream analyses. These embryos were compared to stage-matched WT embryos.

\section{Morpholinos}

Morpholinos used in this study were: tp53 (Robu et al., 2007) and lama5 (Nagendran et al., 2015; Webb et al., 2007). $1 \mathrm{ng}$ of each morpholino was injected into one-cell stage embryos. 
Zebrafish samples were fixed in 4\% PFA in 1X PBS, followed by dechorionation. Briefly, samples were blocked for 1 hour in $2 \mathrm{mg} \mathrm{ml}^{-1}$ BSA and $1 \%$ Goat Serum (Thermo Fisher) in $1 X$ PBSTXD (1X PBS, 0.1\% Tween-20, 0.1\% Triton X-100 and 1\% DMSO). Then, samples were incubated in primary antibody (see below) overnight at $4{ }^{\circ} \mathrm{C}$. Samples were washed in 1X PBSTXD every 15 minutes for 2 hours and then incubated in secondary antibody in room temperature for at least 4 hours, followed by washing with 1X PBSTXD. Counter stains for nuclei was DAPI, and for Actin was Phalloidin (Alexa488 conjugated). When using anti$\gamma \mathrm{H} 2 \mathrm{AX}$ as primary antibody, all PBS buffers were substituted with TBS buffers, and blocking buffer consisted of 3-5\% BSA only.

TUNEL assays were performed between the blocking step and primary antibody incubation step. Samples were washed in 1X PBST (1X PBS, 0.1\% Tween-20) three times, 5 minutes each. After aspiration of the buffer, samples were incubated in the Fluorescein TUNEL kit (Roche) for 1 hour at $37^{\circ} \mathrm{C}$ with gentle shaking. 1X PBST washes were performed to stop the reaction before proceeding with the remaining step of the immunofluorescence protocol.

Primary antibodies used in this study were: anti-Yap1 (CS4912, Cell Signalling), 1:250; antiWwtr1 (D24E4, Cell Signalling), 1:250; anti-P63 (ab735, Abcam), 1:500; anti-ZO1 (1A12, Thermo Fisher), 1:250; anti-phosphoH3 (9701, Cell Signalling), 1:500; anti-cleaved-Caspase3 (ab13847, Abcam), 1:250; and anti- $\gamma \mathrm{H} 2 \mathrm{AX}$ (GTX127342, Genetex), 1:500, anti E-cadherin (610182, BD Transduction Labs), 1:100.

Secondary antibodies used in this study were: Alexa fluorophore-conjugated anti-mouse and anti-rabbit by Thermo Fisher used at 1:500 dilution.

Caspase-8 Assay

Embryos were injected with 10-15 pg H2A-mCherry mRNA at the one-cell stage. At 16 ss, mutant and WT embryos were identified and dechorionated, then incubated in FITC-IETDFMK (ab65614, Abcam) for 30 minutes at room temperature. Embryos were washed with egg water 3 times, 5 minutes each, and then mounted for confocal imaging.

\section{Proliferation assay}

Embryos were imaged from the lateral side. After imaging, embryos were genotyped and only yap 1;wwtr 1 double mutants were compared with stage-matched WT embryos. A maximum intensity projection was generated for each embryo. The yolk was manually demarcated as a 'region of interest', followed by manual identification and counting of phospho-HistoneH3 foci. Poisson regression for count data was used to test whether the number of phospho-HistoneH3 foci differ between WT and mutants.

\section{Yap1/Wwtr1 immunostaining quantification}

Nuclei were segmented with DAPI in order to get total intensity of Yap1, Wwtr1 and P63. peridermal nuclei were excluded from the analysis. The intensity of interests are normalised with DAPI intensity. Nuclei were grouped as P63-positive and P63-negative. T-tests were performed between the P63-positive and P63-negative groups for each normalised Yap1 and Wwtr1 intensity. 
Live and fixed embryos were embedded in 1\% LMA (Sigma) on glass-bottomed dish (inverted microscopes) or petri dish (upright microscopes). For low-magnification images of the entire embryo, a 10x objective lens was used. Otherwise, high-magnification images were taken with 40x objective (water dipping) or 63x objective (water immersion) lens with at least 1 NA was used. For the ventricular inflation experiment, the stretched region of the head epidermis was flattened and mounted using a coverslip, and imaged on the Zeiss LSM 880 confocal microscope with a Plan-APOCHROMAT $63 \mathrm{x} / 1.4$ oil objective at a $1.5 x$ optical zoom.

\section{Live imaging}

Embryos from incrosses of yap 1;wwtrl double heterozygous animals were injected with 10 pg of H2A-mCherry and lyn-EGFP mRNA each at the one-cell stage. At 90\% epiboly, 6-10 embryos were dechorionated and embedded laterally in $0.5 \%$ LMA on a glass-bottomed dish to be imaged under the spinning disk system (Yokogawa CSU-W1). A z-stack of 41 slices, $0.5 \mu \mathrm{m}$ thick, were acquired per embryo every 2 minutes overnight in an environmental chamber set at $28.5^{\circ} \mathrm{C}$. At most 8 embryos were imaged in a single sitting. Embryos were

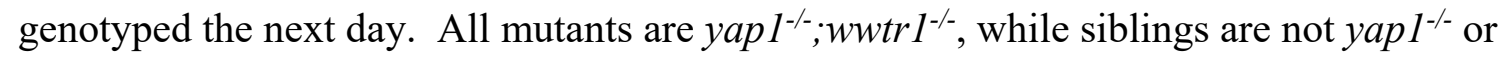
wwtr $1^{-1}$.

\section{Cell size quantification}

Maximum intensity projections of each embryo were generated for each time point. Basal cells were distinguished from EVL cells manually. The lyn-EGFP marks the cell membrane which was manually demarcated to measure cell size every 5 frames. When a cell divides, it marks the start or end of the tracking. For dying cells in mutants, the tracking stops one frame before the DNA condenses.

\section{Western Blot}

16-18 ss mutant embryos (visually identified) and stage-matched WT embryos were dechorionated and collected in separate Eppendorf tubes. A total of 20 embryos from each group were pooled into one tube to constitute a biological replicate. In 1X PBS, embryos were mechanically de-yolked with a pipette tip. Samples were washed in cold 1X PBS thrice, and then 4X Laemmli Sample Buffer (Biorad) with B-mercapthoethanol (Sigma) was added. Samples were vortexed and boiled at $95^{\circ} \mathrm{C}$ for 5 minutes three times. Samples were stored in $-20^{\circ} \mathrm{C}$ until ready for use.

Proteins from each sample were resolved using a precast 8-16\% gradient gel (Biorad), and transferred to a PVDF membrane following manufacturer's protocol. Membranes were blocked with 3-5\% BSA in 1X TBST (1X TBS, 0.5\% Tween-20) for an hour, followed by incubation with primary antibody overnight at $4^{\circ} \mathrm{C}$. Membranes were washed with $1 \mathrm{X}$ TBST before incubation with secondary antibody for at least 1 hour. Membranes were washed again with 1X TBST. ECL substrate (Biorad) was added to the membrane and imaged with the ChemiDoc imaging system (Biorad).

The primary antibodies used in this assay are: anti-B-actin (A5441, Sigma), 1:1000; anti$\gamma \mathrm{H} 2 \mathrm{AX}$ (GTX127342, Genetex), 1:1000.

The secondary antibodies used in this assay are: HRP-conjugated anti-mouse (31430, Thermo Fisher), 1:10000; HRP-conjugated anti-rabbit (31460, Thermo Fisher), 1:10000. 
The head epidermis was stretched by injecting hydrophobic mineral oil (Bio-Rad; 1632129) into the hindbrain ventricle of $24 \mathrm{hpf}$ zebrafish, as previously described (Lewis et al., 2020). In brief, at $24 \mathrm{hpf}$ the dechorionated embryos were anaesthetised in $0.02-0.024 \%$ (w/v in E3) tricaine, and vertically mounted in holes punched in a $3 \%(\mathrm{w} / \mathrm{v})$ agarose plate. This was followed by either stretching the epidermis by injecting 10-12 $\mathrm{nL}$ mineral oil in the hindbrain ventricle (Stretched) or injecting only 0.1-0.2 $\mathrm{nL}$ oil to act as an injury control (Sham). All embryos used in a set were obtained from the same clutch and were injected using the same capillary needle, to reduce variation. The test and sham embryos were grown in E3 until fixation an hour later.

\section{HaCaT Cell culture}

All cell culture reagents were purchased from Gibco (ThermoFisher Scientific, MA, USA). The human immortalised keratinocyte cell line, HaCaT, was a gift from CT Lim Lab (MBI, Singapore). HaCaT keratinocytes were cultured in complete Dulbecco's modified Eagle's medium (DMEM) that was supplemented with 100 I.U./mL aqueous penicillin, $100 \mu \mathrm{g} / \mathrm{ml}$ streptomycin and 10\% heat-inactivated fetal bovine serum (FBS). Cells were maintained at $37^{\circ} \mathrm{C}$ in a humidified atmosphere containing 5\% CO2 and harvested with TrypLE (1X). TrypLE was deactivated with complete media. Cells were pelleted by centrifugation at $180 \times$ $\mathrm{g}$ for 5 minutes and then re-suspended in complete media. The cell suspensions were used only when their viability, as assessed by trypan blue exclusion, exceeded $95 \%$. Briefly, $0.1 \mathrm{~mL}$ of $0.4 \%$ of trypan blue solution was added to $0.1 \mathrm{~mL}$ of cell suspension. Cell viability and density were calculated with a hemocytometer.

$\mathrm{HaCaT}$ cells were then seeded on $0.5 \mathrm{kPa}, 12 \mathrm{kPa}$ and $25 \mathrm{kPa}$ collagen-coated Softslips (Matrigen, CA, USA), as well as glass cover slips in individual wells of a 24-well plate. 50,000 cells were seeded on each substrate. Seeded cells were incubated for 10 hours or overnight for cells to completely attach to the substrates.

\section{HaCaT Cell immunofluorescence assay}

HaCaT cells were fixed with 4\% PFA in $1 \mathrm{X}$ PBS for 15 minutes. After washing off residual PFA with 1X TBSX (1X TBS supplemented with $0.1 \%$ Triton X-100), samples were incubated with blocking solution (4\% BSA in 1XTBSX) for 1 hour. Samples were then incubated in primary antibody diluted in blocking solution overnight at $4{ }^{\circ} \mathrm{C}$. After washing off the primary antibody solution with $1 \mathrm{X}$ TBSX, samples were incubated in secondary antibodies and counterstains diluted in blocking solution for 2 hours, followed by washes with 1X TBSX. Hydrogel-coated coverslips (Softslips) were inverted unto a coverslip for imaging according to manufacturer's instructions.

$\gamma H 2 A X$ foci quantification in HaCaT cells

Nuclei of HaCaT cells were marked as regions of interest for counting the number of $\gamma \mathrm{H} 2 \mathrm{AX}$ foci. Background signal was subtracted using a rolling radius of 5 pixels. A focus is at least 5 pixels in area size, and the number of foci was counted for each nucleus. To test the increase of $\gamma \mathrm{H} 2 \mathrm{AX}$ foci in the UV-treated group, one-sided T-tests were performed between $\mathrm{UV}$ and control groups for each substrate stiffness. To test the change of the number of $\gamma \mathrm{H} 2 \mathrm{AX}$ foci by different substrate stiffness, control HaCaT cells cultured on $0.5 \mathrm{kPa}$ 
391 hydrogels was used as the reference in two-sided T-tests. $P$-values were adjusted for multiple

392 hypothesis testing with the Tukey method.

393 UV Exposure

39424 hpf zebrafish embryos or HaCaT cells were exposed to UV in the Biosafety Cabinet. UV

395 dose for zebrafish experiment was $63.2 \mathrm{~mJ} / \mathrm{cm}^{2}$, while UV dose for HaCaT cells was 30.6

$396 \mathrm{~mJ} / \mathrm{cm}^{2}$. After UV exposure, samples were allowed to recover for an hour (zebrafish in a

$39729.0^{\circ} \mathrm{C}$ incubator; HaCaT cells in $37.0^{\circ} \mathrm{C}$ humidified incubator). 


\section{ACKNOWLEDGEMENTS}

400 The yap ${ }^{\text {bns22 }}$ zebrafish allele was generated by JKHL in Didier Stainier's lab (MPI, Bad 401 Nauheim), and we thank him for his support. We also thank Boon Chuan Low (MBI, 402 Singapore), Mahendra Sonawane (TIFR, India) and Tom Carney (NTU, Singapore) for 403 insightful discussions and suggestions. This work was funded by the Singapore Ministry of 404 Education Tier 3 grant MOE2016-T3-1-002 and Mechanobiology Institute core funding.

405

406

\section{COMPETING INTERESTS}

407 The authors declare that no competing interests exist.

408 


\section{FIGURE LEGENDS}

Figure 1. Developing zebrafish yap1;wwtr1 double mutants show aberrant epidermal basal cell death. (A) Maximum intensity projections of 16-18 ss WT and mutant embryos stained with TUNEL and P63. Scale bars, $100 \mu \mathrm{m}$. (B) Maximum intensity projections of the epidermis on the lateral yolk of 6-8 ss mutant and normal siblings stained with TUNEL, P63 and ZO-1. Yellow arrowheads indicate TUNEL and P63 double positive nuclei. Scale bars, $10 \mu \mathrm{m}$. (B') Quantification of TUNEL-positive EBC nuclei (P63+) and apoptotic fragments (fragments).

Figure 2. Yap1 and Wwtr1 are localised in EBCs and EVL cells. Maximum intensity projections of the epidermis on the lateral yolk stained with P63, and Wwtr1 or Yap1 antibodies at indicated developmental stages. Insets, demarcated in red, show overlay of P63 and Yap1/Wwtr1. Arrowheads - P63-positive basal cells; arrows - peridermal cells; triangles - peridermal cell junctions. Scale bars, $10 \mu \mathrm{m}$.

Figure 3. Concurrent loss of yap1 and wwtr1 did not impair epidermal cell proliferation. (A) Maximum intensity projections of 3-5 ss WT and mutant embryos stained with a proliferation marker, phospho-histone $\mathrm{H} 3$ (phosphoH3; pH3), and phalloidin. Scale bars, $100 \mu \mathrm{m}$. (B) Boxplot of the number of $\mathrm{pH} 3$ cells on the lateral side of the yolk of WT and mutant zebrafish embryos. mut - yap 1;wwtrl double mutants.

Figure 4. Zebrafish yap1 $1^{--}$;wwtr $1^{-/-}$epidermal cells exhibit DNA damage and extrinsic apoptotic cell death. (A) Maximum intensity projections of 6-8 ss WT and mutant epidermis on the lateral yolk stained with cleaved Caspase- 3 (*Caspase-3) and P63. Some *Caspase-3 positive cells are also P63 positive (yellow arrow heads). Scale bars, $10 \mu \mathrm{m}$. (A') Number of EBCs (P63+) and apoptotic fragments (fragments) expressing cleaved Caspase- 3 in WT and mutant embryo epidermis. ' $\mathrm{X}$ ' represents the median, while the whiskers projecting from it represent the interquartile range. (B) Maximum intensity projections of the epidermis on the lateral yolk of 20-22 ss WT and mutant embryos expressing H2A-mCherry. Embryos were incubated in a Caspase- 8 chemical probe, FITCIETD-FMK, prior to imaging. FITC signal indicates Caspase- 8 activity in cells (yellow arrowheads). Scale bars, $10 \mu \mathrm{m}$. (B') Number of FITC foci in WT and mutant embryo epidermis. ' $\mathrm{X}$ ' represents the median, while the whiskers projecting from it represent the interquartile range. (C) Maximum intensity projections of 18-22 ss WT and mutant epidermis on the lateral yolk stained with $\gamma \mathrm{H} 2 \mathrm{AX}$ and P63. Some nuclei are positive for both markers (yellow arrowheads). Scale bars, $10 \mu \mathrm{m}$. (C') Number of EBCs (P63+) and apoptotic fragments (fragments) expressing $\gamma \mathrm{H} 2 \mathrm{AX}$ in WT and mutant embryo epidermis. ' $\mathrm{X}$ ' represents the median, while the whiskers projecting from it represent the interquartile range.

Figure 5. Epidermal cell size of sibling and mutant embryos during development. Cell size was measured with a membrane marker during live imaging of mutant and sibling 
embryos from the tailbud stage. Fine lines are the size of individual cells, while bold lines are the average cell size in a single embryo. Skull symbols mark cell size and time before death (DNA condensation).

454

Figure 6. $\gamma \mathrm{H} 2 \mathrm{AX}$ in stretched epidermal cells and in keratinocytes cultured on different substrate stiffness. (A) Schematic of head epidermal cell stretching experiment in zebrafish embryos. (A') Sham $(n=6)$ and stretched $(n=6)$ head epidermal cells stained with $\gamma \mathrm{H} 2 \mathrm{AX}$ and epidermal markers (E-Cadherin and P63). P63 is a marker for EBCs. No discernible $\gamma \mathrm{H} 2 \mathrm{AX}$ signal was detected in both conditions. Scale bars, $10 \mu \mathrm{m}$. (B) Selected nuclei of HaCaT cells cultured on $0.5 \mathrm{kPa}, 12.0 \mathrm{kPa}, 25.0 \mathrm{kPa}$ hydrogels and glass, as well as boxplot of the number of $\gamma \mathrm{H} 2 \mathrm{AX}$ foci in these nuclei. Number of $\gamma \mathrm{H} 2 \mathrm{AX}$ foci in HaCaT cell nuclei were contrasted against $\mathrm{HaCaT}$ cells cultured on $0.5 \mathrm{kPa}$ hydrogel using T-tests. Data were collected from 3 independent experiments. $* * *-P<0.001$ adjusted for multiple testing

464 (Tukey method). 
Figure 2-figure supplement 1. Yap1 and Wwtr1 are localised to the nuclei of EBCs, and Yap1's Tead-Binding Domain is essential in EBC survival. Boxplots of normalised intensities of Yap1 and Wwtr1 in the nucleus of P63-positive and P63-negative cells in the basal epidermis. T-tests were carried out to compare these intensities between the two groups. $* * *-P<0.001$. (B) Schematic of the encoded protein product of the zebrafish yap 1 WT and bns22 alleles. S54 is necessary for Yap1 binding to Teads. (B') Maximum intensity projections of 16-18 ss WT and yap1 $1^{\text {bns22/bns22 }}$;wwtr $1^{-/-}$embryos stained with TUNEL and P63. Scale bars, $100 \mu \mathrm{m}$.

Figure 4-figure supplement 1. Aberrant cell death and increased $\gamma \mathrm{H2AX}$ levels in mutants. (A) Maximum intensity projections of 18-20 ss WT and mutant embryos injected with H2A-mCherry mRNA only (no MO) or co-injected with tp53 morpholino (tp53 MO). Blocking of tp53 did not have any observable effect on cell death in both WT and mutant embryos. Scale bars $100 \mu \mathrm{m}$. (B) Western Blot of $\gamma \mathrm{H} 2 \mathrm{AX}$ and B-Actin (loading control). Each lane is a biological replicate of pooled 18-20 ss WT and mutant embryos. Ladder on far left lane with annotated size (in kD).

Figure 6-figure supplement 1. $\gamma \mathrm{H} 2 \mathrm{AX}$ in zebrafish head epidermis and HaCaT cells embryos stained with $\gamma \mathrm{H} 2 \mathrm{AX}$ and epidermal markers (E-Cadherin and P63). P63 is a marker for EBCs. EBCs (yellow arrowheads) and peridermal cells (yellow arros) exposed to UV exhibit pan-nuclear $\gamma \mathrm{H} 2 \mathrm{AX}$. (B) Selected nuclei of control and UV-treated HaCaT cells cultured on $0.5 \mathrm{kPa}, 12 \mathrm{kPa}, 25 \mathrm{kPa}$ hydrogels and glass, and boxplots of the number of $\gamma \mathrm{H} 2 \mathrm{AX}$ foci in these nuclei. T-tests on control groups were compared against control HaCaT cells cultured on $0.5 \mathrm{kPa}$ hydrogel. T-tests on UV groups were compared against their respective controls (brackets). Data were collected from 3 independent experiments. $* * *-P$ $<0.001$ adjusted for multiple testing. projections of the epidermis on the lateral yolk of mutant and sibling embryos. Membranes and nuclei are marked by Lyn-EGFP (green) and H2A-mCherry (red), respectively. Time stamp format, HH:MM; 00:00 is tailbud stage.

Movie S2. Apoptosis of mutant basal cells. Time lapse of mutant basal cells undergoing apoptosis as captured by live imaging. Membranes and nuclei are marked by Lyn-EGFP (green) and H2A-mCherry (red), respectively. Time stamp format, HH:MM; 00:00 is tailbud 
502 Figure 1-source data 1. TUNEL count data for Figure 1B'

503 Figure 3-source data 1. pH3 count data for Figure 3B

504 Figure 4-source data 1. Casp3, Casp8 and $\gamma \mathrm{H} 2 \mathrm{AX}$ count data for Figures 4A', B' and C', 505 respectively.

506 Figure 5-source data 1. Measured cell size from live imaging experiment for Figure 5.

507 Figure 6-source data 1. $\gamma \mathrm{H} 2 \mathrm{AX}$ foci count data for Figure 6B.

508 Figure 2-figure supplement 1-source data 1. Normalized Yap1 and Wwtr1 intensity 509 measurements for Figure 2-figure supplement 1A.

510 Figure 4-figure supplement 1-source data 1. Raw image files of Western Blot assay for 511 Figure 4-figure supplement 1B.

512 Figure 6-figure supplement 1-source data 1. $\gamma \mathrm{H} 2 \mathrm{AX}$ foci count data for Figure 6-figure 513 supplement $1 \mathrm{~B}$. 


\section{REFERENCES}

Astone, M., Lai, J. K. H., Dupont, S., Stainier, D. Y. R., Argenton, F., \& Vettori, A. (2018). Zebrafish mutants and TEAD reporters reveal essential functions for Yap and Taz in posterior cardinal vein development. Scientific Reports, 8(1), 10189. https://doi.org/10.1038/s41598-018-27657-x

Bakkers, J., Hild, M., Kramer, C., Furutani-Seiki, M., \& Hammerschmidt, M. (2002). Zebrafish $\Delta \mathrm{Np} 63$ is a direct target of Bmp signaling and encodes a transcriptional repressor blocking neural specification in the ventral ectoderm. Developmental Cell, 2(5), 617-627. https://doi.org/10.1016/S1534-5807(02)00163-6

Bang, B., Gniadecki, R., Larsen, J. K., Baadsgaard, O., \& Skov, L. (2003). In vivo UVB irradiation induces clustering of Fas (CD95) on human epidermal cells. Experimental Dermatology, 12(6), 791-798. https://doi.org/10.1111/j.0906-6705.2003.00091.x

Blanpain, C., \& Fuchs, E. (2006). Epidermal Stem Cells of the Skin. Annual Review of Cell and Developmental Biology, 22(1), 339-373. https://doi.org/10.1146/annurev.cellbio.22.010305.104357

Cognart, H. A., Viovy, J. L., \& Villard, C. (2020). Fluid shear stress coupled with narrow constrictions induce cell type-dependent morphological and molecular changes in SKBR-3 and MDA-MB-231 cells. Scientific Reports, 10(1), 1-14. https://doi.org/10.1038/s41598-020-63316-w

Dong, J., Feldmann, G., Huang, J., Wu, S., Zhang, N., Comerford, S. a, Gayyed, M. F., Anders, R. a, Maitra, A., \& Pan, D. (2007). Elucidation of a universal size-control mechanism in Drosophila and mammals. Cell, 130(6), 1120-1133. https://doi.org/10.1016/j.cell.2007.07.019

Elbediwy, A., Vincent-Mistiaen, Z. I., Spencer-Dene, B., Stone, R. K., Boeing, S., Wculek, S. K., Cordero, J., Tan, E. H., Ridgway, R., Brunton, V. G., Sahai, E., Gerhardt, H., Behrens, A., Malanchi, I., Sansom, O. J., \& Thompson, B. J. (2016). Integrin signalling regulates YAP and TAZ to control skin homeostasis. Development, 143(10), 1674-1687. https://doi.org/10.1242/dev.133728

Engler, A. J., Sen, S., Sweeney, H. L., \& Discher, D. E. (2006). Matrix Elasticity Directs Stem Cell Lineage Specification. Cell, 126(4), 677-689. https://doi.org/10.1016/j.cell.2006.06.044

Flinn, M. A., Otten, C., Brandt, Z. J., Bostrom, J. R., Kenarsary, A., Wan, T. C., Auchampach, J. A., Abdelilah-Seyfried, S., O’Meara, C. C., \& Link, B. A. (2020). Llgl1 regulates zebrafish cardiac development by mediating Yap stability in cardiomyocytes. Development (Cambridge, England), 147(16). https://doi.org/10.1242/dev.193581

Guillermin, O., Angelis, N., Sidor, C. M., Ridgway, R., Baulies, A., Kucharska, A., Antas, P., Rose, M. R., Cordero, J., Sansom, O., Li, V. S. W., \& Thompson, B. J. (2021). Wnt and Src signals converge on YAP-TEAD to drive intestinal regeneration. The EMBO Journal, 1-19. https://doi.org/10.15252/embj.2020105770

Hill, L. L., Ouhtit, A., Loughlin, S. M., Kripke, M. L., Ananthaswamy, H. N., \& OwenSchaub, L. B. (1999). Fas ligand: A sensor for DNA damage critical in skin cancer etiology. Science, 285(5429), 898-900. https://doi.org/10.1126/science.285.5429.898

Jänicke, M., Carney, T. J., \& Hammerschmidt, M. (2007). Foxi3 transcription factors and 
Notch signaling control the formation of skin ionocytes from epidermal precursors of the zebrafish embryo. Developmental Biology, 307(2), 258-271. https://doi.org/10.1016/j.ydbio.2007.04.044

Johnson, R., \& Halder, G. (2014). The two faces of Hippo: targeting the Hippo pathway for regenerative medicine and cancer treatment. Nature Reviews Drug Discovery, 13(1), 6379. https://doi.org/10.1038/nrd4161

Kim, J., Kim, Y. H., Kim, J., Park, D. Y., Bae, H., Lee, D.-H., Kim, K. H., Hong, S. P., Jang, S. P., Kubota, Y., Kwon, Y.-G., Lim, D.-S., \& Koh, G. Y. (2017). YAP/TAZ regulates sprouting angiogenesis and vascular barrier maturation. The Journal of Clinical Investigation, 127(9), 3441-3461. https://doi.org/10.1172/JCI93825

Kimelman, D., Smith, N. L., Lai, J. K. H., \& Stainier, D. Y. R. (2017). Regulation of posterior body and epidermal morphogenesis in zebrafish by localized Yap1 and Wwtr1. ELife, 6, 1-29. https://doi.org/10.7554/eLife.31065

Kumar, A., Mazzanti, M., Mistrik, M., Kosar, M., Beznoussenko, G. V., Mironov, A. A., Garrè, M., Parazzoli, D., Shivashankar, G. V., Scita, G., Bartek, J., \& Foiani, M. (2014). ATR mediates a checkpoint at the nuclear envelope in response to mechanical stress. Cell, 158(3), 633-646. https://doi.org/10.1016/j.cell.2014.05.046

Lai, J. K. H., Collins, M. M., Uribe, V., Jiménez-Amilburu, V., Günther, S., Maischein, H.M., \& Stainier, D. Y. R. (2018). The Hippo pathway effector Wwtr1 regulates cardiac wall maturation in zebrafish. Development (Cambridge, England), 145(10), dev159210. https://doi.org/10.1242/dev.159210

Lewis, N. S., Chouhan, G., Belapurkar, V., Arora, P., Satyanarayan, Ainavarapu, S. R. K., \& Sonawane, M. (2020). A new tension induction paradigm unravels tissue response and the importance of E-cadherin in the developing epidermis. International Journal of Developmental Biology, 64(1-3), 333-342. https://doi.org/10.1387/ijdb.190219ms

Ma, K., Xu, Q., Wang, S., Zhang, W., Liu, M., Liang, S., Zhu, H., \& Xu, N. (2016). Nuclear accumulation of Yes-Associated Protein (YAP) maintains the survival of doxorubicininduced senescent cells by promoting survivin expression. Cancer Letters, 375(1), 84 91. https://doi.org/10.1016/j.canlet.2016.02.045

Miesfeld, J. B., Gestri, G., Clark, B. S., Flinn, M. a., Poole, R. J., Bader, J. R., Besharse, J. C., Wilson, S. W., \& Link, B. a. (2015). Yap and Taz regulate retinal pigment epithelial cell fate. Development (Cambridge, England), 142(17), 3021-3032. https://doi.org/10.1242/dev.119008

Nagendran, M., Arora, P., Gori, P., Mulay, A., Ray, S., Jacob, T., \& Sonawane, M. (2015). Canonical Wnt signalling regulates epithelial patterning by modulating levels of laminins in zebrafish appendages. Development, 142(11), 2080-2080. https://doi.org/10.1242/dev.125849

Nair, S., Marlow, F., Abrams, E., Kapp, L., Mullins, M. C., \& Pelegri, F. (2013). The Chromosomal Passenger Protein Birc5b Organizes Microfilaments and Germ Plasm in the Zebrafish Embryo. PLoS Genetics, 9(4). https://doi.org/10.1371/journal.pgen.1003448

Nakajima, H., Yamamoto, K., Agarwala, S., Terai, K., Fukui, H., Fukuhara, S., Ando, K., Miyazaki, T., Yokota, Y., Schmelzer, E., Belting, H.-G., Affolter, M., Lecaudey, V., \& Mochizuki, N. (2017). Flow-Dependent Endothelial YAP Regulation Contributes to 
601

602

603

604

605

606

607

608

609

610

611

612

613

614

615

616

617

618

619

620

621

622

623

624

625

626

627

628

629

630

631

632

633

634

635

Vessel Maintenance. Developmental Cell, 40(6), 523-536.e6. https://doi.org/10.1016/j.devcel.2017.02.019

Neto, F., Klaus-Bergmann, A., Ong, Y. T., Alt, S., Vion, A. C., Szymborska, A., Carvalho, J. R., Hollfinger, I., Bartels-Klein, E., Franco, C. A., Potente, M., \& Gerhardt, H. (2018). YAP and TAZ regulate adherens junction dynamics and endothelial cell distribution during vascular development. ELife, 7, 1-30. https://doi.org/10.7554/eLife.31037

Papatheodorou, I., Moreno, P., Manning, J., Fuentes, A. M. P., George, N., Fexova, S., Fonseca, N. A., Füllgrabe, A., Green, M., Huang, N., Huerta, L., Iqbal, H., Jianu, M., Mohammed, S., Zhao, L., Jarnuczak, A. F., Jupp, S., Marioni, J., Meyer, K., ... Brazma, A. (2020). Expression Atlas update: From tissues to single cells. Nucleic Acids Research, 48(D1), D77-D83. https://doi.org/10.1093/nar/gkz947

Reginensi, A., Hoshi, M., Boualia, S. K., Bouchard, M., Jain, S., \& McNeill, H. (2015). Yap and Taz are required for Ret-dependent urinary tract morphogenesis. Development (Cambridge, England), 142(15), 2696-2703. https://doi.org/10.1242/dev.122044

Robu, M. E., Larson, J. D., Nasevicius, A., Beiraghi, S., Brenner, C., Farber, S. A., \& Ekker, S. C. (2007). P53 Activation By Knockdown Technologies. PLoS Genetics, 3(5), 787801. https://doi.org/10.1371/journal.pgen.0030078

Solnica-Krezel, L. (2005). Conserved patterns of cell movements during vertebrate gastrulation. Current Biology, 15(6), 213-228. https://doi.org/10.1016/j.cub.2005.03.016

Takahashi, H. (2001). Ultraviolet B irradiation induces apoptosis of keratinocytes by direct activation of fas antigen. Journal of Investigative Dermatology Symposium Proceedings, 6(1), 64-68. https://doi.org/10.1046/j.0022-202x.2001.00020.x

Wang, X., Freire Valls, A., Schermann, G., Shen, Y., Moya, I. M., Castro, L., Urban, S., Solecki, G. M., Winkler, F., Riedemann, L., Jain, R. K., Mazzone, M., Schmidt, T., Fischer, T., Halder, G., \& Ruiz de Almodóvar, C. (2017). YAP/TAZ Orchestrate VEGF Signaling during Developmental Angiogenesis. Developmental Cell, 42(5), 462-478.e7. https://doi.org/10.1016/j.devcel.2017.08.002

Webb, A. E., Sanderford, J., Frank, D., Talbot, W. S., Driever, W., \& Kimelman, D. (2007). Laminin $\alpha 5$ is essential for the formation of the zebrafish fins. Developmental Biology, 311(2), 369-382. https://doi.org/10.1016/j.ydbio.2007.08.034

Zhao, B., Ye, X., Yu, J., Li, L., Li, W., Li, S., Yu, J., Lin, J. D., Wang, C.-Y., Chinnaiyan, A. M., Lai, Z.-C., \& Guan, K.-L. (2008). TEAD mediates YAP-dependent gene induction and growth control. Genes \& Development, 22(14), 1962-1971.

https://doi.org/10.1101/gad.1664408 
bioRxiv preprint doi: https://doi org/10.1101/2021.07.23.453490; this version posted July 23, 2021. The copyright holder for this preprint (which was not certified by peer review) is the author/funder, who has granted bioRxiv a license to display the preprint in perpetuity. It is made available under aCC-BY 4.0 International license.
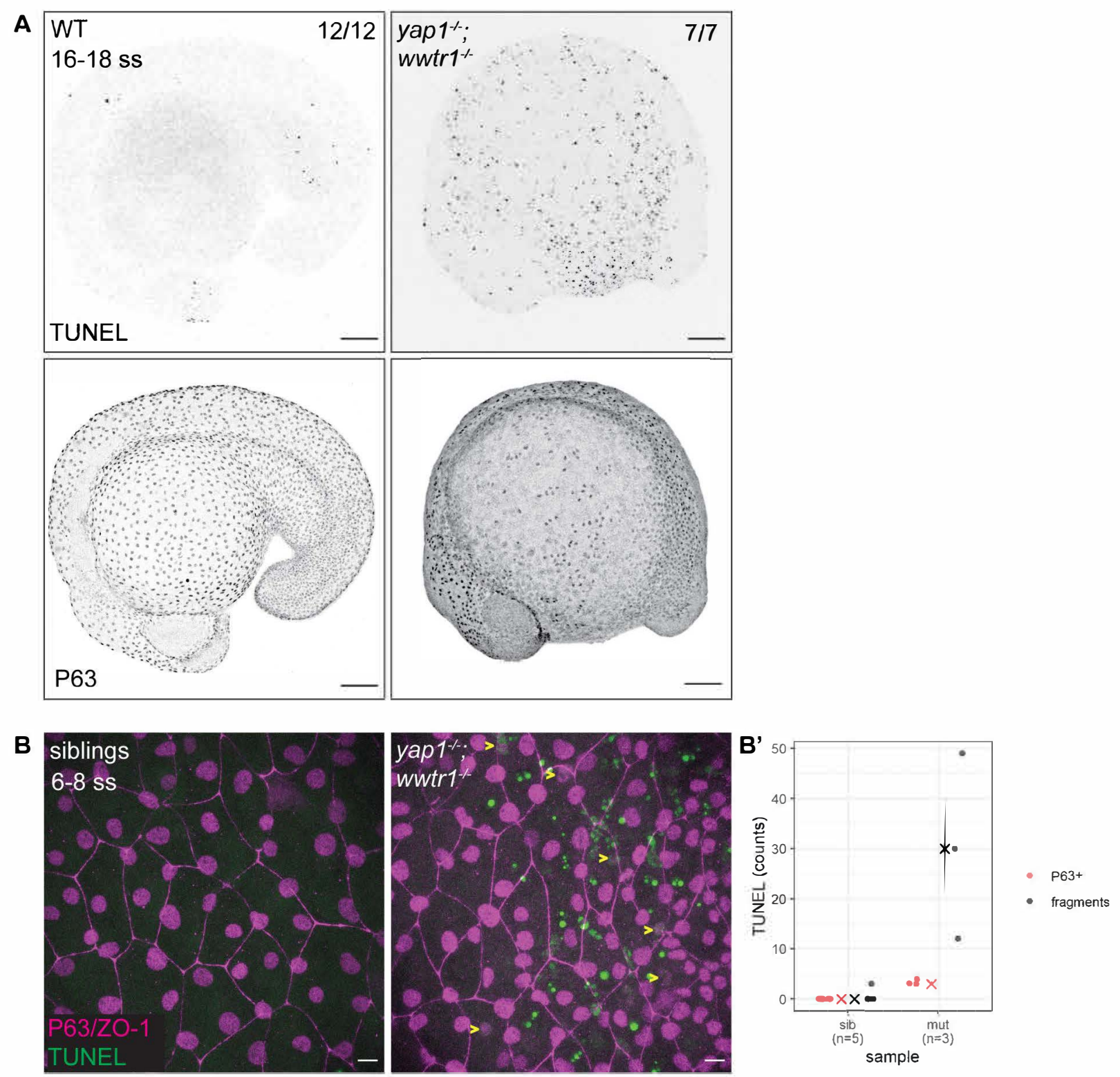
bioRxiv preprint doi: https://doi.org/10.1101/2021.07.23.453490; this version posted July 23, 2021. The copyright holder for this preprint (which was not certified by peer review) is the author/funder, who has granted bioRxiv a license to display the preprint in perpetuity. It is made available under aCC-BY 4.0 International license.

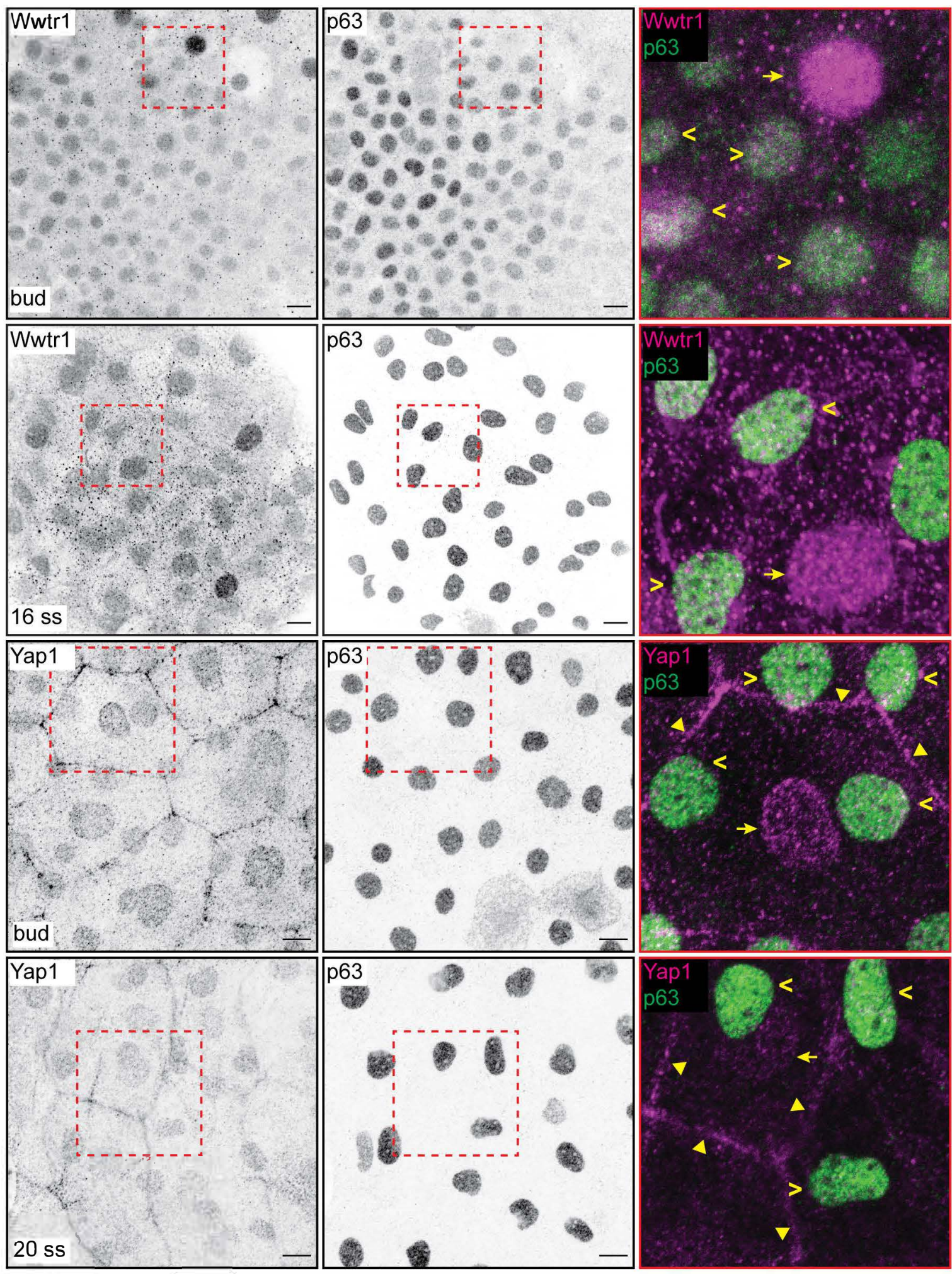


bioRxiv preprint doi: https://doi.org/10.1101/2021.07.23.453490; this version posted July 23, 2021. The copyright holder for this preprint (which was not certified by peer review) is the author/funder, who has granted bioRxiv a license to display the preprint in perpetuity. It is made available under aCC-BY 4.0 International license.

A phosphoH3

phalloidin

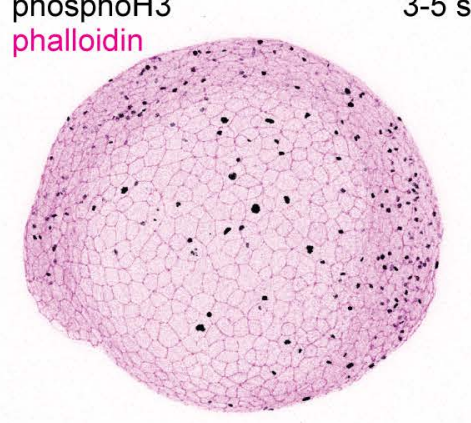

WT
3-5 ss

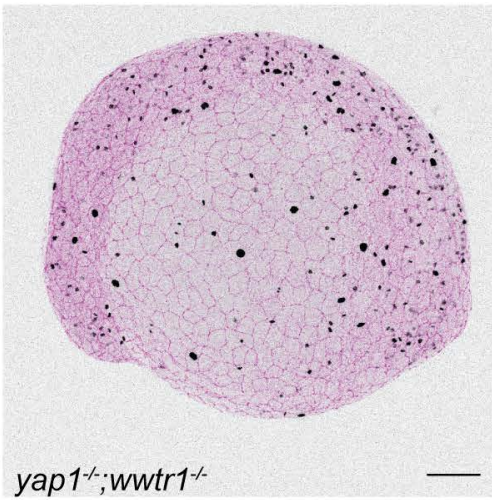

B

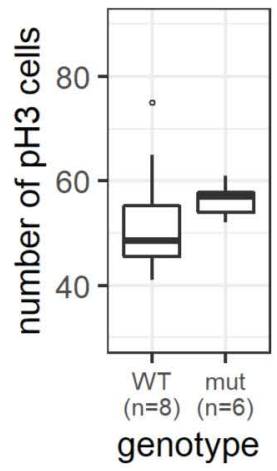

Figure 3 
bioRxiv preprint doi: https://doi.org/10.1101/2021.07.23.453490; this version posted July 23, 2021. The copyright holder for this preprint (which was not certified by peer review) is the author/funder, who has granted bioRxiv a license to display the preprint in perpetuity. It is made available under aCC-BY 4.0 International license.

A

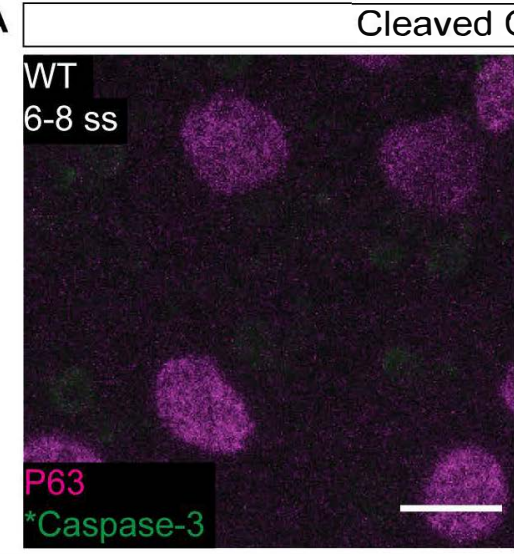

B

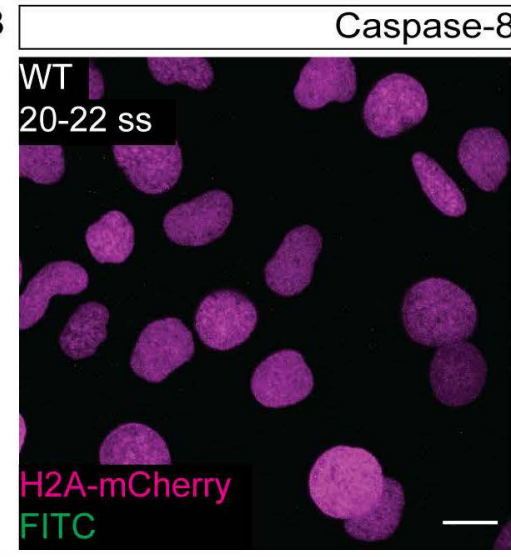

C

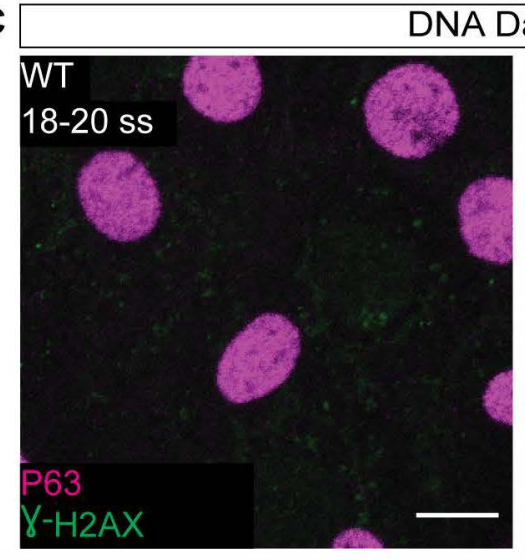

A'
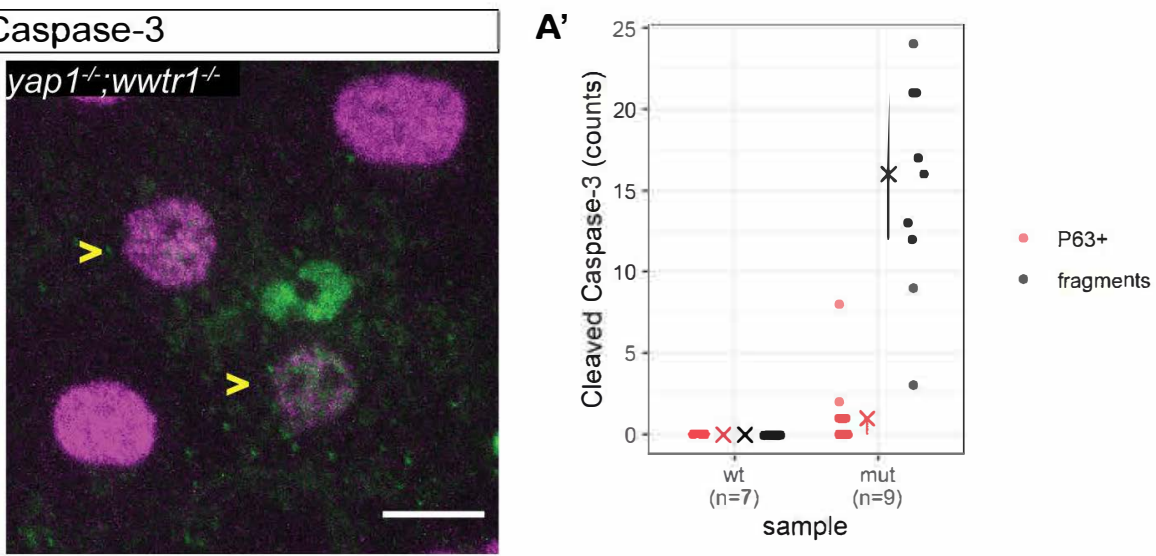

B'
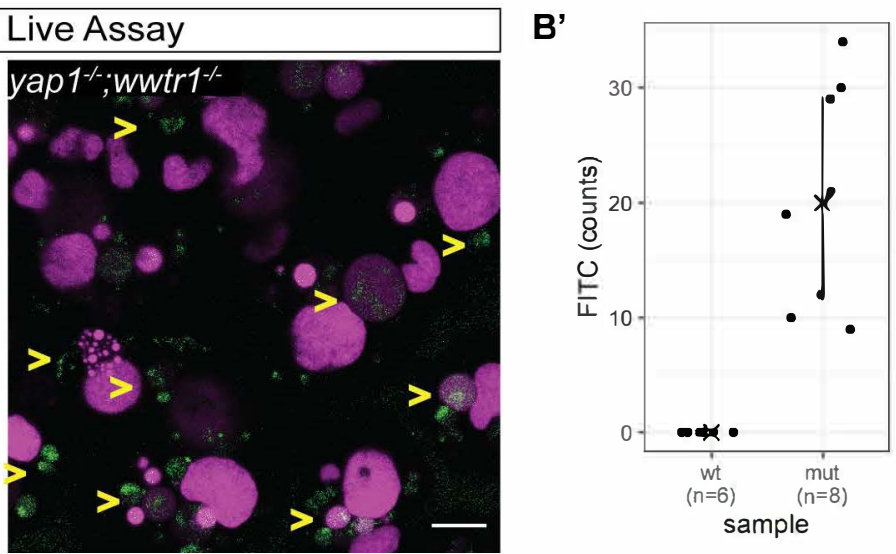

C'

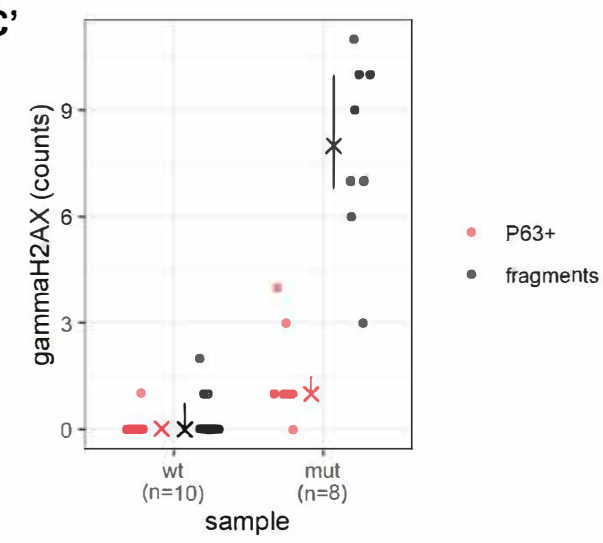


bioRxiv preprint doi: https://doi.org/10.1101/2021.07.23.453490; this version posted July 23, 2021. The copyright holder for this preprint (which was not certified by peer review) is the author/funder, who has granted bioRxiv a license to display the preprint in perpetuity. It is made available under aCC-BY 4.0 International license.

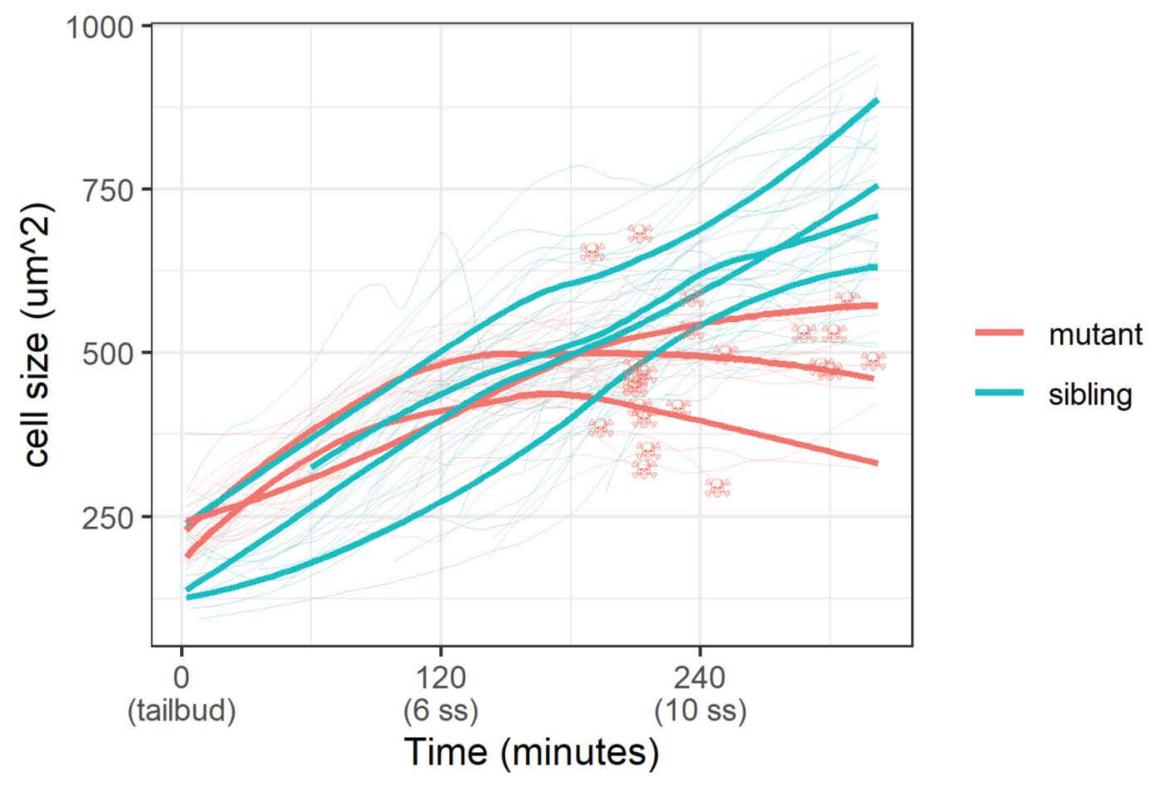

Figure 5 
bioRxiv preprint doi: https://doi.org/10.1101/2021.07.23.453490; this version posted July 23, 2021. The copyright holder for this preprint
A Sham (which was not certified by peer review) is the author/funder, who has granted bioRxiv a license to display the preprint in perpetuity. It is

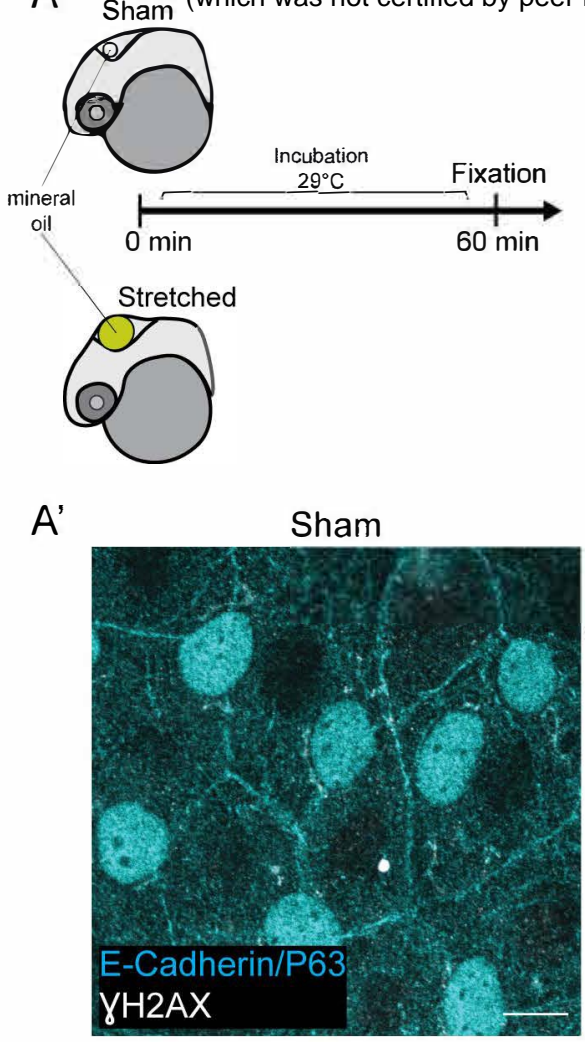

Stretched

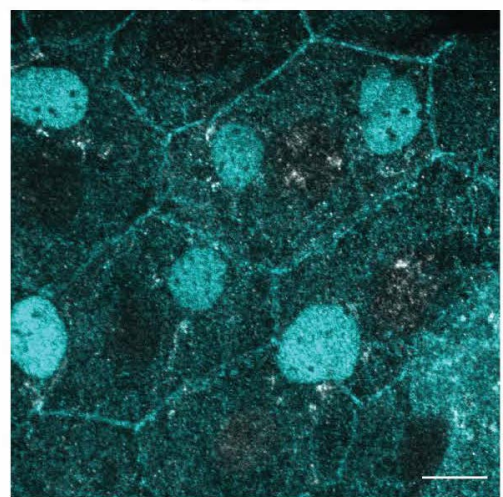
made available under aCC-BY 4.0 International license.

substrate stiffness

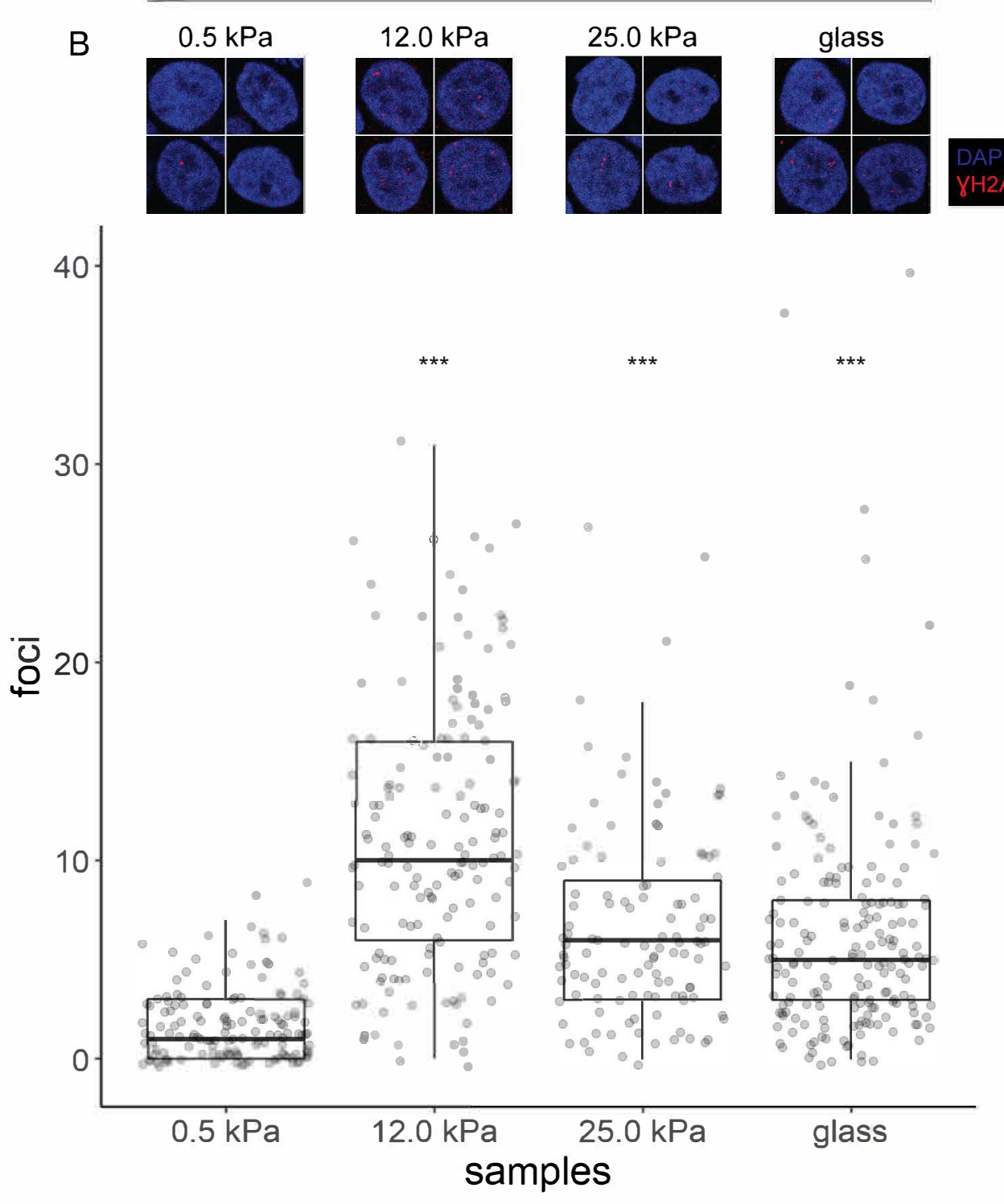


bioRxiv preprint doi: https://doi.org/10.1101/2021.07.23.453490; this version posted July 23, 2021. The copyright holder for this preprint

A (which was not certified by peer review) is the author/funder, who has granted bioRxiv a license to display the preprint in perpetuity. It is

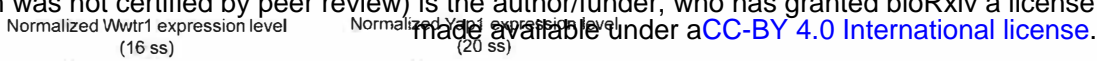
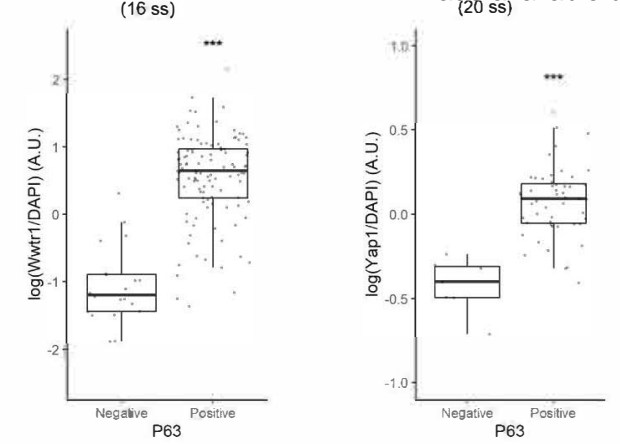

B

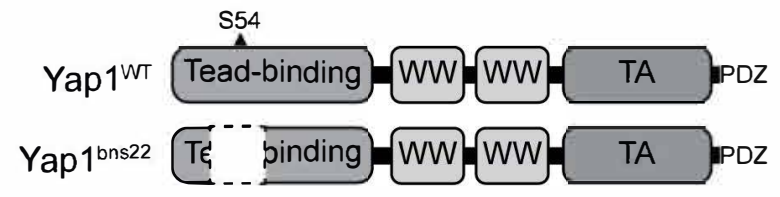

B'

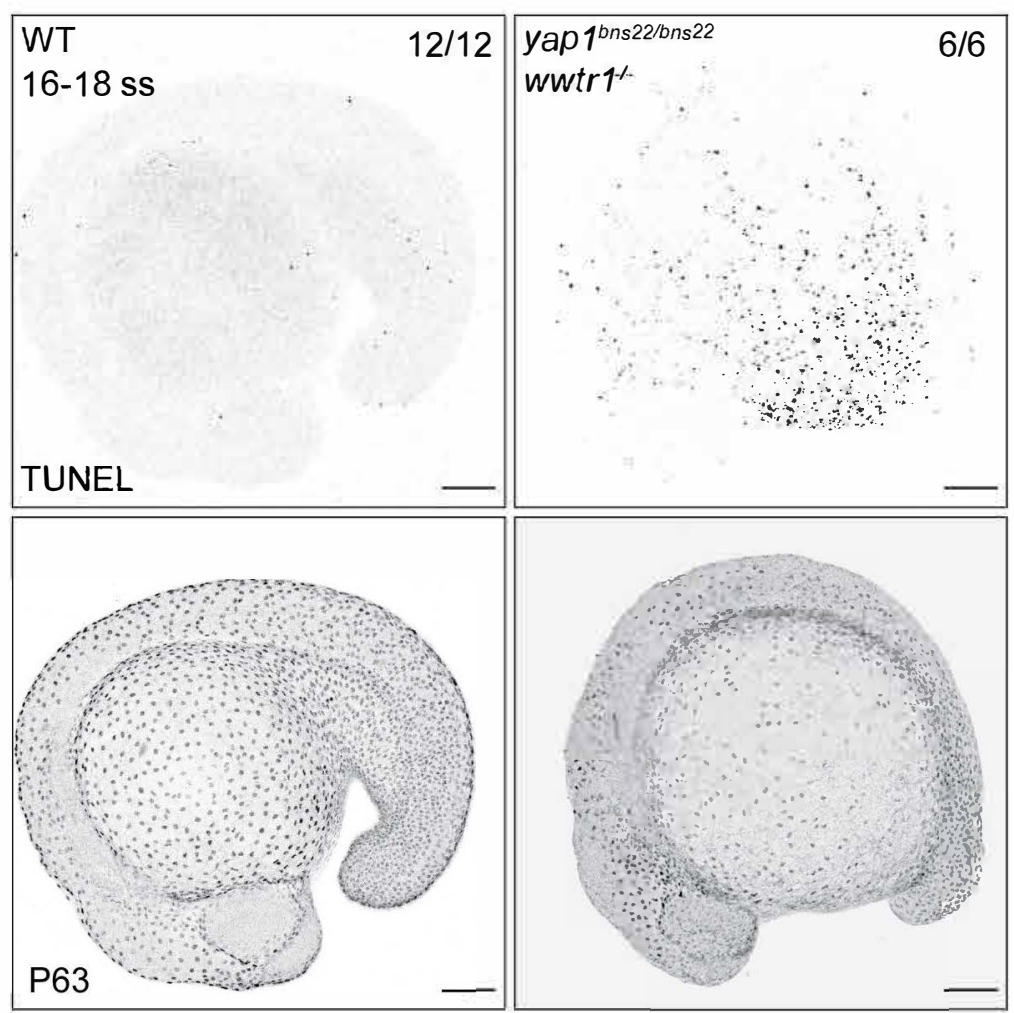


bioRxiv preprint doi: https://doi.org/10.1101/2021.07.23.453490; this version posted July 23, 2021. The copyright holder for this preprint (which was not certified by peer review) is the author/funder, who has granted bioRxiv a license to display the preprint in perpetuity. It is made available under aCC-BY 4.0 International license.
A WT
$7 / 7$ yap $1^{-/} ;$wwtr $^{\text {- }}$
$9 / 9$
B
yap $1^{-}$
no $\mathrm{MO}$
no $\mathrm{MO}$
${ }_{20} \stackrel{\text { WT }}{15} \frac{w w t r 1^{-}}{\gamma-\mathrm{H} 2 \mathrm{AX}}$
50
B-Actin
37

$18-20$ ss

WT

tp53 MO

7/7 уар1\%,

tp53 MO

$9 / 9$

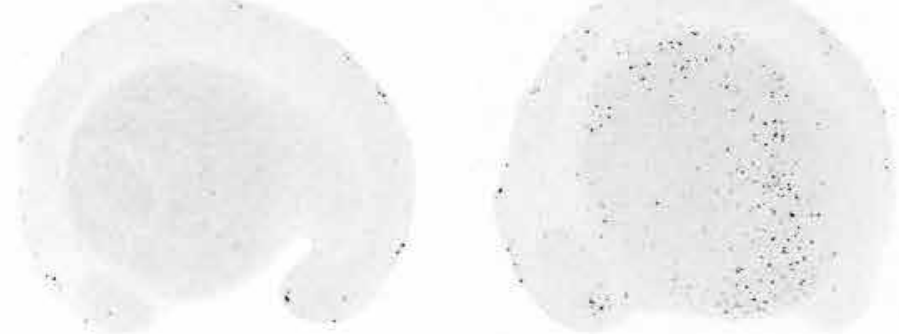

TUNEL 
bioRxiv preprint doi: $\mathrm{https}$ ://doi.org/10.1101/2021.07 23.453490; this version posted July 23, 2021. The copyright holder for this preprint (which was not certified by peer review) is the author/funder, who has granted bioRxiv a license to display the preprint in perpetuity. It is A Control made availaple under aCC-BY 4.0 International license.

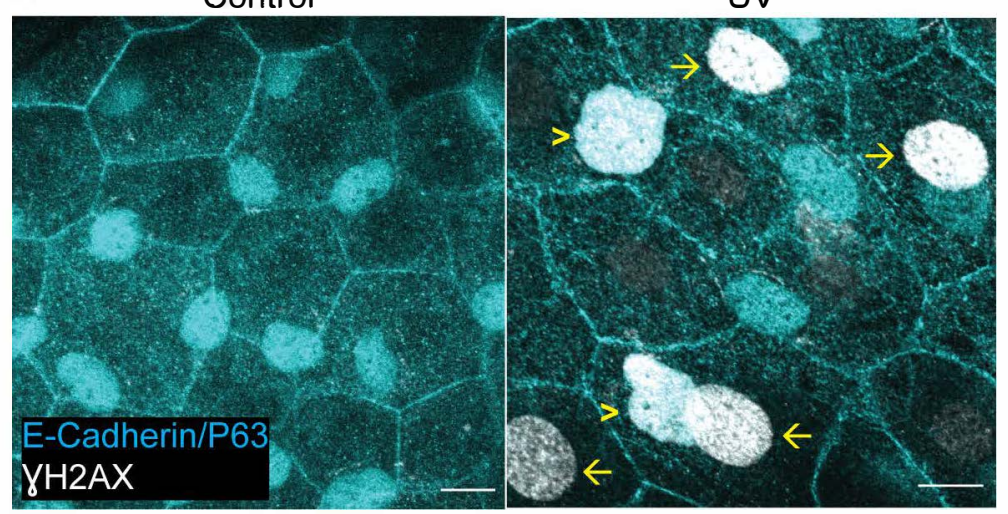

B
$0.5 \mathrm{kPa}$

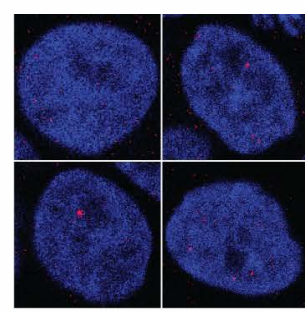

UV

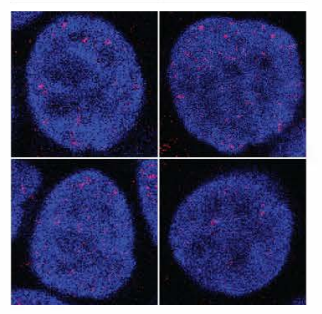

$12.0 \mathrm{kPa}$
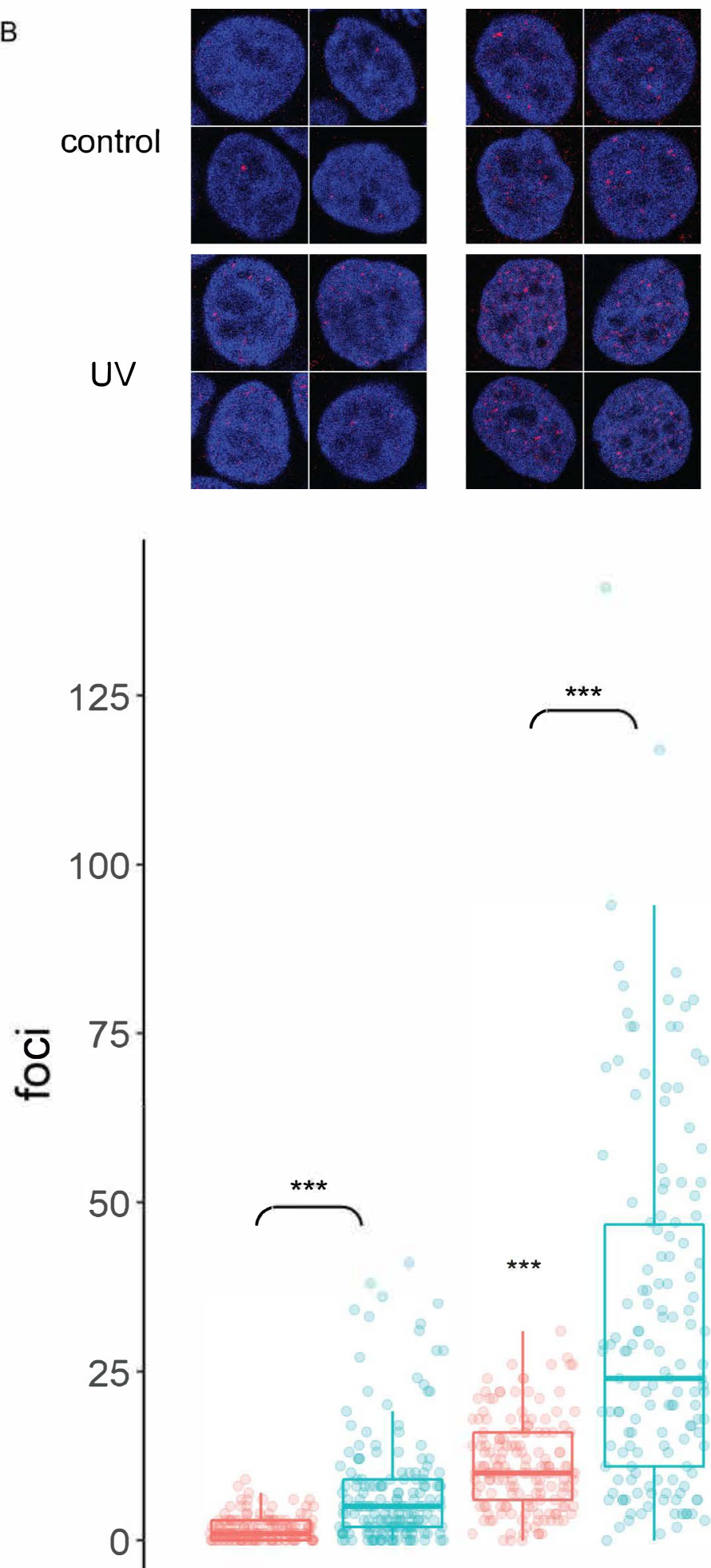

125

$-$

control
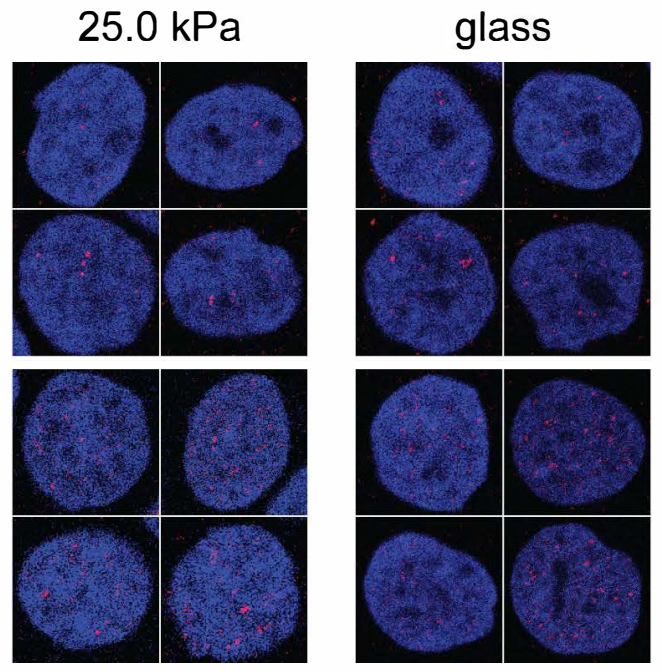

DAPI
YH2AX

glass

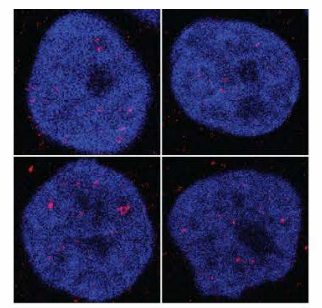

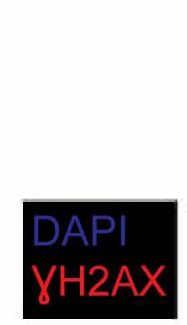

treatment

审 control 白 UV 